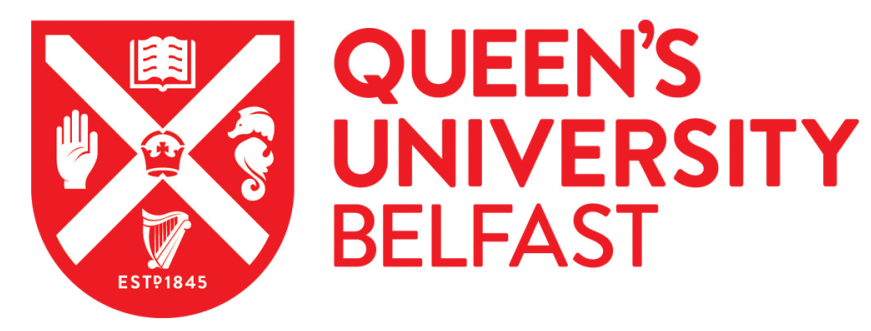

\title{
Interactions between non-flooded mulching cultivation and varying nitrogen inputs in rice-wheat rotations
}

Fan, M. S., Jiang, R. F., Liu, X. J., Zhang, F. S., Lu, S. H., Zeng, X. Z., \& Christie, P. (2005). Interactions between non-flooded mulching cultivation and varying nitrogen inputs in rice-wheat rotations. Field Crops Research, 91(2-3), 307-318. https://doi.org/10.1016/j.fcr.2004.08.006

Published in:

Field Crops Research

Queen's University Belfast - Research Portal:

Link to publication record in Queen's University Belfast Research Portal

\section{General rights}

Copyright for the publications made accessible via the Queen's University Belfast Research Portal is retained by the author(s) and / or other copyright owners and it is a condition of accessing these publications that users recognise and abide by the legal requirements associated with these rights.

Take down policy

The Research Portal is Queen's institutional repository that provides access to Queen's research output. Every effort has been made to ensure that content in the Research Portal does not infringe any person's rights, or applicable UK laws. If you discover content in the Research Portal that you believe breaches copyright or violates any law, please contact openaccess@qub.ac.uk. 


\title{
Interactions between non-flooded mulching cultivation and varying nitrogen inputs in rice-wheat rotations
}

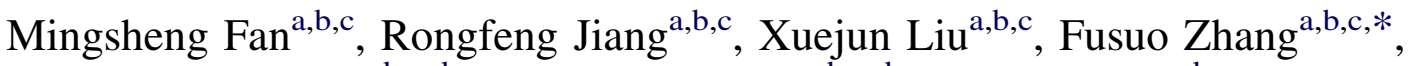 \\ Shihua $\mathrm{Lu}^{\mathrm{a}, \mathrm{b}, \mathrm{c}, \mathrm{d}}$, Xiangzhong Zeng ${ }^{\mathrm{a}, \mathrm{b}, \mathrm{c}, \mathrm{d}}$, Peter Christie ${ }^{\mathrm{a}, \mathrm{b}, \mathrm{c}, \mathrm{e}}$ \\ ${ }^{a}$ Department of Plant Nutrition, China Agricultural University, Ministry of Agriculture, Beijing 100 094, China \\ ${ }^{\mathrm{b}}$ Key Laboratory of Plant Nutrition, Ministry of Agriculture, Beijing 100 094, China \\ ${ }^{\mathrm{c}}$ Key Laboratory of Plant-Soil Interactions, Ministry of Education, Beijing 100 094, China \\ ${ }^{\mathrm{d}}$ Institute of Soils and Fertilizers, Sichuan Academy of Agricultural Sciences, Chengdu 610 066, China \\ ${ }^{\mathrm{e}}$ School of Agriculture and Food Science, Queen's University Belfast, Belfast BT9 5PX, UK
}

Received 22 December 2003; received in revised form 29 July 2004; accepted 1 August 2004

\begin{abstract}
A 3-year field experiment examined the effects of non-flooded mulching cultivation and traditional flooding and four fertilizer $\mathrm{N}$ application rates $\left(0,75,150\right.$ and $225 \mathrm{~kg} \mathrm{ha}^{-1}$ for rice and $0,60,120$, and $180 \mathrm{~kg} \mathrm{~N} \mathrm{ha}^{-1}$ for wheat) on grain yield, $\mathrm{N}$ uptake, residual soil $\mathrm{N}_{\min }$ and the net $\mathrm{N}$ balance in a rice-wheat rotation on Chengdu flood plain, southwest China. There were significant grain yield responses to $\mathrm{N}$ fertilizer. Nitrogen applications of $>150 \mathrm{~kg} \mathrm{ha}^{-1}$ for rice and $>120 \mathrm{~kg} \mathrm{ha}^{-1}$ for wheat gave no increase in crop yield but increased crop $\mathrm{N}$ uptake and $\mathrm{N}$ balance surplus in both water regimes. Average rice grain yield increased by $14 \%$ with plastic film mulching and decreased by $16 \%$ with wheat straw mulching at lower N inputs compared with traditional flooding. Rice grain yields under SM were comparable to those under PM and TF at higher N inputs. Plastic film mulching of preceding rice did not affect the yield of succeeding wheat but straw mulching had a residual effect on succeeding wheat. As a result, there was 17-18\% higher wheat yield under N0 in SM than those in PM and TF. Combined rice and wheat grain yields under plastic mulching was similar to that of flooding and higher than that of straw mulching across $\mathrm{N}$ treatments. Soil mineral N (top $60 \mathrm{~cm}$ ) after the rice harvest ranged from 50 to $65 \mathrm{~kg} \mathrm{ha}^{-1}$ and was unaffected by non-flooded mulching cultivation and $\mathrm{N}$ rate. After the wheat harvest, soil $\mathrm{N}_{\min }$ ranged from 66 to $88 \mathrm{~kg} \mathrm{~N} \mathrm{ha}^{-1}$ and increased with increasing fertilizer $\mathrm{N}$ rate. High $\mathrm{N}$ inputs led to a positive $\mathrm{N}$ balance $\left(160-621 \mathrm{~kg} \mathrm{ha}^{-1}\right)$, but low $\mathrm{N}$ inputs resulted in a negative balance ( -85 to $-360 \mathrm{~kg} \mathrm{ha}^{-1}$ ). Across $\mathrm{N}$ treatments, the net $\mathrm{N}$ balances of $\mathrm{SM}$ were highest among the three cultivations systems, resulting from additional applied wheat straw $\left(79 \mathrm{~kg} \mathrm{ha}^{-1}\right)$ as mulching materials. There was not clear trend found in net $\mathrm{N}$ balance between PM and TF. Results from this study indicate non-flooded mulching cultivation may be utilized as an alternative option for saving water, using efficiently straw and maintaining or improving crop yield in rice-wheat rotation systems. There is the
\end{abstract}

Abbreviations: TF, traditional flooding cultivation; PM, plastic film mulching; SM, wheat straw mulching; R, rice; W, wheat; R-W, ricewheat; $\mathrm{N}$, nitrogen; $\mathrm{P}$, phosphorus; $\mathrm{K}$, potassium; $\mathrm{N}_{\text {min }}$, soil mineral $\mathrm{N}$; N0, N1, N2 and N3, fertilizer $\mathrm{N}$ application rates of $0,75,150$ and $225 \mathrm{~kg} \mathrm{~N} \mathrm{ha}^{-1}$ for rice and $0,60,120$, and $180 \mathrm{~kg} \mathrm{~N} \mathrm{ha}^{-1}$ for wheat

* Corresponding author. Tel.: +8610 62892499; fax: +86 1062891016.

E-mail address: zhangfs@cau.edu.cn (F. Zhang). 
need to evaluate the long-term environmental risks of non-flooded mulching cultivation and improve system productivity (especially with straw mulching) by integrated resource management.

(C) 2004 Elsevier B.V. All rights reserved.

Keywords: Rice-wheat cropping systems; Non-flooded mulching cultivation; Productivity; Nitrogen balance; Plastic film; Straw management

\section{Introduction}

Rice-wheat rotations are practiced widely along the Yangtze River Basin where they occupy a total area of about 13 million ha (Timsina and Connor, 2001). These systems include the complete range from flooded rice to strategically irrigated or rain fed wheat. However, the amount of fresh water available for irrigation is becoming scarce and this threatens the sustainability of rice-based cropping systems (Bouman, 2001). Lowland rice, which accounts for about $50 \%$ of the total amount of water diverted for irrigation in Asia (Bouman and Tuong, 2001), offers great likelihood to save irrigation water because the physiological water requirement of rice $\left(4500 \mathrm{~m}^{3}\right.$ water $\mathrm{ha}^{-1}$ ) is much smaller than its actual water consumption and is comparable to that of some upland crops (Guerra et al., 1998). The management of crop straw and its impact on nutrient cycling and soil fertility are also issues that are important to agricultural sustainability. The traditional disposal method for rice and wheat straw in many parts of the world is burning (Yoshinori and Kanno, 1997). The burning of wheat straw is popular in China because of the short turnaround time between the wheat harvest and rice transplanting in rice-wheat rotations. Estimated losses are up to $80 \%$ of $\mathrm{N}$ (Raison, 1979), $25 \%$ of $\mathrm{P}$ and $21 \%$ of $\mathrm{K}$ (Ponnamperuma, $1984)$ in addition to the problem of air pollution. Furthermore, declining or stagnating yield have been observed in rice-based cropping systems (Cassman et al., 1997; Dobermann and Witt, 2000). Improvements are therefore required in the management of soil, water and straw.

A new rice cultivation technique, non-flooded mulching cultivation, was introduced in the late 1980s. Lowland rice fields are irrigated and a shallow water layer is maintained before transplanting. The soil surface is then covered with plastic film $(0.005-$ $0.010 \mathrm{~mm}$ thick) or crop straw and the soil is maintained at $70-90 \%$ of water holding capacity or rain fed during the rice development stage (Liang et al., 2000). Some experiments have tested the effects of this new cultivation technique on rice yield and soil fertility. Plastic film mulching (PM) led to increased or maintained rice yield (Wu et al., 1999; Liang et al., 1999; Fan et al., 2002), but soil organic C and soil total $\mathrm{N}$ in a paddy field under PM conditions were subject to depletion (Hu et al., 1999). Retention of crop residues on the soil surface increased organic $\mathrm{C}$ and total $\mathrm{N}$ in the top $5-15 \mathrm{~cm}$ of the soil (Rasmussen and Collins, 1991), while straw mulching cultivation (SM) resulted in decreased or maintained rice yields (Liu et al., 2003; Fan et al., 2002).

Nevertheless, information is still limited on the effects of non-flooded mulching cultivation of rice on the productivity and sustainability of rice-wheat rotations. A unique feature of lowland rice-wheat systems is the annual conversion of soil from aerobic to anaerobic conditions and then back to aerobic conditions. Non-flooded mulching cultivation alters the environment of growing rice through changes in soil water conditions and leads to a prolonged aerobic phase in rice-wheat rotations. This makes the conservation of soil organic matter and soil $\mathrm{N}$ in cropping systems difficult, especially under PM. Concerns have been raised on the potential of nonflooded mulching cultivation to affect the productivity of rice-wheat rotations. Furthermore, a change from traditional flooding (anaerobic) to non-flooded mulching (aerobic) and the effects of non-flooded mulching cultivation on soil temperature (Liu et al., 2003; Peng et al., 1999; Parker and Larson, 1962) are likely to exert large influences on $\mathrm{N}$ forms and availability and $\mathrm{N}$ cycling. Return of straw can also lead to temporary nutrient limitation due to microbial immobilization (Rao and Mikkelsen, 1976; Jenkinson, 1985). It is therefore important to test interactions between varying $\mathrm{N}$ inputs and non-flooded mulching cultivation and their effects on productivity and $\mathrm{N}$ cycling in rice-wheat systems. 
As part of our evaluation of non-flooded mulching cultivation, the objectives of the present study were to determine the effects of non-flooded mulching cultivation and fertilizer $\mathrm{N}$ application rate on crop yield, $\mathrm{N}$ uptake, residual soil $\mathrm{N}_{\min }$ and the net $\mathrm{N}$ balance. This information is required for the development of integrated management practices to optimize the productivity and sustainability of ricewheat rotations.

\section{Materials and methods}

\subsection{Field experiment}

A detailed description of the experimental site and soil, crop and water management has been presented elsewhere (Liu et al., 2003). Briefly, the site was located at the center of Chengdu flood plain. The sandy loam soil contained $18.4 \mathrm{~g} \mathrm{~kg}^{-1}$ organic matter, $1.8 \mathrm{~g} \mathrm{~kg}^{-1}$ total $\mathrm{N}, \quad 5.5 \mathrm{mg} \mathrm{kg}^{-1}$ Olsen-P and $40.0 \mathrm{mg} \mathrm{kg}^{-1} \mathrm{NH}_{4} \mathrm{OAc}$-exchangeable $\mathrm{K}$. The soil is classified as Stagnic Anthrosols and has a pH of 7.2. The experiment was established in the year 2000.

Treatments were laid out in a split-plot randomized complete block design in triplicate. Main plot treatments were the three cultivation systems: traditional flooding (TF), plastic film mulching (PM) and wheat straw mulching (SM) in the rice season, and zero tillage cultivation in the wheat season. Split-plot treatments were four $\mathrm{N}$ rates: N0 (no fertilizer $\mathrm{N}$ for either rice or wheat), $\mathrm{N} 1\left(75 \mathrm{~kg} \mathrm{~N} \mathrm{ha}^{-1}\right.$ for rice and $60 \mathrm{~kg} \mathrm{~N} \mathrm{ha}^{-1}$ for wheat), $\mathrm{N} 2\left(150 \mathrm{~kg} \mathrm{~N} \mathrm{ha}^{-1}\right.$ for rice and $120 \mathrm{~kg} \mathrm{~N} \mathrm{ha}^{-1}$ for wheat), and $\mathrm{N} 3\left(225 \mathrm{~kg} \mathrm{~N} \mathrm{ha}^{-1}\right.$ for rice and $180 \mathrm{~kg} \mathrm{~N} \mathrm{ha}^{-1}$ for wheat) as urea. The $\mathrm{N}$, $\mathrm{P}$ and $\mathrm{K}$ fertilizers $\left(90 \mathrm{~kg} \mathrm{P}_{2} \mathrm{O}_{5} \mathrm{ha}^{-1}\right.$ as calcium superphosphate and $90 \mathrm{~kg} \mathrm{~K}_{2} \mathrm{O} \mathrm{ha}^{-1}$ as potassium sulfate) were incorporated into the top $15 \mathrm{~cm}$ of the soil in all treatments by ploughing prior to transplanting of rice. In the wheat season, the $\mathrm{P}$ and $\mathrm{K}$ fertilizers $\left(60 \mathrm{~kg} \mathrm{P}_{2} \mathrm{O}_{5} \mathrm{ha}^{-1}\right.$ as calcium superphosphate, $60 \mathrm{~kg}$ $\mathrm{K}_{2} \mathrm{O} \mathrm{ha}{ }^{-1}$ as potassium sulfate) and $50 \%$ of the $\mathrm{N}$ fertilizer were applied to the seedbeds of all plots just before sowing and the remaining half of the $\mathrm{N}$ fertilizer was broadcast in early February at the booting stage of wheat.

Traditional flooding and non-flooded plots were separated by a 2-m-wide alley using plastic film inserted into the soil to a depth of $60 \mathrm{~cm}$, and other plots were separated by a 0.5 -m-wide irrigation furrow and two $0.3-\mathrm{m}$ levees. The size of all plots was $3 \mathrm{~m} \times$ $5 \mathrm{~m}$. Plastic film, $0.005 \mathrm{~mm}$ thick and $1.7 \mathrm{~m}$ wide, was used to cover the soil in the PM treatment. Wheat straw, harvested from the same field (about $5250 \mathrm{~kg}$ DM ha ${ }^{-1}$ containing $26 \mathrm{~kg} \mathrm{~N}^{-1}$ ) was used to cover the soil in the SM treatment. The rice (Oryza sativa L.) varieties used, the hybrid 'Gangyou 527' in the first 2 years and 'Xiangyou 1' in 2002, were supplied by the Institute of Crop Science, Sichuan Academy of Agricultural Sciences (SAAS). The dates of rice transplanting and harvesting were late May (23-26) and mid-September (15-19) during the 3-year period from 2000 to 2002.

After the rice harvest each year, wheat (Triticum aestivum L.) was planted on the same plots with zero tillage and the removal of rice straw. In early November (2-6), the wheat variety 'SW3243', supplied by the Institute of Crop Science, SAAS, was sown directly into the soil at two spacings of $10 \mathrm{~cm} \times 15 \mathrm{~cm}$ and $10 \mathrm{~cm} \times 25 \mathrm{~cm}$ as bunch planting. Most of the residual plastic film was removed from the field before sowing the wheat in the PM treatment. The wheat was harvested in mid-May (10-17) the following year (from 2001 to 2003).

\subsection{Soil and plant analysis}

Soil samples from 0-20, 20-40 and 40-60 cm depths from all plots were collected with a $3-\mathrm{cm}$ i.d. tube auger and separated into $20-\mathrm{cm}$ depth increments at both wheat and rice harvests over the 3 years. Soil samples were frozen or refrigerated without delay. Within $12 \mathrm{~h}$ a $12-\mathrm{g}$ moist soil sub-sample was extracted with $100 \mathrm{ml} 0.01 \mathrm{M} \mathrm{CaCl}_{2}$. The extracts were analyzed for $\mathrm{NO}_{3}{ }^{-}-\mathrm{N}$ and $\mathrm{NH}_{4}{ }^{+} \mathrm{N}$ by Continuous Flow Analysis (Bran and Luebbe TRAACS Model 2000 Analyzer). Simultaneously, another subsample was weighed in a pre-weighed aluminium can for determination of soil water content. Ammonium and nitrate values $\left(\mathrm{mg} \mathrm{kg}^{-1}\right)$ were converted to $\mathrm{kg} \mathrm{Nha}^{-1}$ using soil bulk density concurrently determined with soil cores from each depth.

Grain and straw yields were determined by harvesting the whole plot without two border rows of each treatment. Rice grain yields were adjusted to $140 \mathrm{~g} \mathrm{~kg}^{-1}$ moisture content while wheat grain yields 
were recorded on a dry matter basis. The plant subsamples (grain and straw) were oven-dried for dry matter content at $60{ }^{\circ} \mathrm{C}$ for $48 \mathrm{~h}$ and were ground and analyzed for $\mathrm{N}$ by the micro-Kjeldahl procedure after wet digestion with $\mathrm{H}_{2} \mathrm{SO}_{4}$ and $\mathrm{H}_{2} \mathrm{O}_{2}$. Nitrogen uptake was calculated as the product of $\mathrm{N}$ concentration and yield of aboveground parts of the crop on a dry matter basis.

\subsection{Net $N$ balance}

The $\mathrm{N}$ balance was calculated by accounting for differences between the inputs and outputs. The calculations were made as follows:

net $\mathrm{N}$ balance $=\mathrm{N}$ additions through fertilizer,

$$
\begin{aligned}
& \text { rainfall, wheat straw and irrigation } \\
& -\mathrm{N} \text { removal by crop }
\end{aligned}
$$

Nitrogen inputs from irrigation water were computed from the estimated total amount of applied irrigation water $(3300 \mathrm{~mm}$ in TF and $280 \mathrm{~mm}$ in PM and SM) in three rice seasons and measurements of ammonium and nitrate in the irrigation water which were made at 15-day intervals in the 2003 rice season. Other major pathways of $\mathrm{N}$ not measured included $\mathrm{N}$ inputs from biological $\mathrm{N}_{2}$ fixation and dry deposition, gaseous $\mathrm{N}$ losses from ammonia volatilization and denitrification, and leaching. The calculated $\mathrm{N}$ balances therefore estimate only net gains or losses.

\subsection{Climatic conditions}

Temperature, rainfall and sunshine hours data are listed for each of the three experimental years (May 2000-2003) in Fig. 1 and show year-to-year variations in temperature and sunshine hours. The maximum temperatures during the summer season and the early winter season were higher in 2001/2002 than in both $2000 / 2001$ and 2002/2003 seasons. In the 2000/2001 season a relatively cold period commenced in November and December. While the timing of the rainy season is relatively predictable, there was considerable variation in the amount, intensity, and distribution of rain. Rainfall totals for the three cropping years were 624,978 , and $819 \mathrm{~mm}$, respectively.

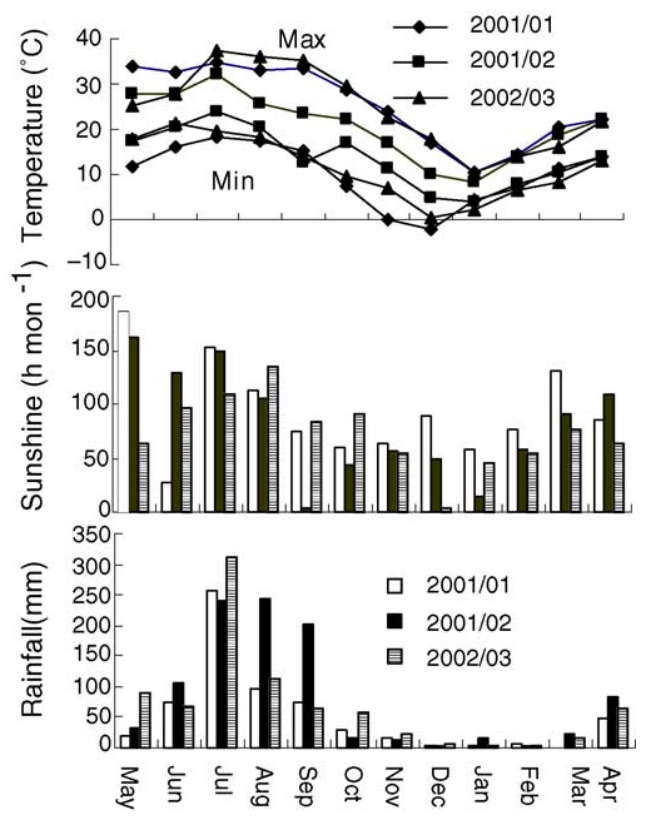

Fig. 1. Temperature (maximum and minimum), rainfall, and sunshine hours for rice-wheat rotations on Chengdu Plain, southwest China during the 2000/01, 2001/02 and 2002/03 seasons. Sunshine hours and rainfall data are monthly totals. Temperatures are the month averages.

\subsection{Statistical analysis}

Analysis of variance was performed using a splitplot model to test for significance of treatments and means were compared by least significance difference (LSD) at the 5\% level (SAS, 1996).

\section{Results}

\subsection{Grain yields}

\subsubsection{Effects of $N$ rate on rice and wheat grain yields}

Significant grain yield responses to $\mathrm{N}$ fertilizer by rice and wheat were evident during the 3-year period (Table 1). Every $\mathrm{N}$-treated plot gave higher average grain yields than zero-N controls. Among $\mathrm{N}$ treatments rice grain yield showed an increasing trend with increasing $\mathrm{N}$ rate. However, there was no significant difference in rice yields between $\mathrm{N} 2$ and $\mathrm{N} 3$ levels. The wheat grain yields in N2 were higher than those in 
Table 1

Effects of non-flooded mulching cultivation and fertilizer $\mathrm{N}$ rate on grain yield of rice and wheat in rice-wheat rotations on Chengdu Plain, southwest China $\left(\mathrm{kg} \mathrm{ha}^{-1}\right)$

\begin{tabular}{|c|c|c|c|c|c|c|c|}
\hline \multirow[t]{2}{*}{ Fertilizer $\mathrm{N}$ rate $\mathrm{a}^{\mathrm{a}}$} & \multirow[t]{2}{*}{ Cultivation system $^{\mathrm{b}}$} & \multicolumn{3}{|l|}{ Rice } & \multicolumn{3}{|l|}{ Wheat } \\
\hline & & 2000 & 2001 & 2002 & $2000 / 2001$ & $2001 / 2002$ & $2002 / 2003$ \\
\hline \multirow[t]{4}{*}{ N0 } & TF & $5266 \mathrm{~b}$ & $5092 \mathrm{~b}$ & $4302 \mathrm{a}$ & $2960 \mathrm{~b}$ & $3029 \mathrm{~b}$ & $3096 \mathrm{a}$ \\
\hline & PM & 6093 a & $6148 \mathrm{a}$ & $4730 \mathrm{a}$ & $3088 \mathrm{~b}$ & $2599 \mathrm{~b}$ & 3444 a \\
\hline & SM & $4041 \mathrm{c}$ & $5579 \mathrm{ab}$ & $3120 \mathrm{~b}$ & $3331 \mathrm{a}$ & $3494 \mathrm{a}$ & $3864 \mathrm{a}$ \\
\hline & No mean ${ }^{c}$ & 5134 & 5606 & 4051 & 3126 & 3060 & 3485 \\
\hline \multirow[t]{4}{*}{ N1 } & $\mathrm{TF}$ & 8237 a & $5998 \mathrm{~b}$ & 5926 a & $4287 \mathrm{a}$ & 4263 a & $4380 \mathrm{a}$ \\
\hline & PM & $7307 \mathrm{a}$ & $6528 \mathrm{a}$ & $5895 \mathrm{a}$ & 4449 a & $3548 \mathrm{~b}$ & $4513 \mathrm{a}$ \\
\hline & SM & $5944 \mathrm{~b}$ & $6236 \mathrm{ab}$ & $4202 \mathrm{~b}$ & $4487 \mathrm{a}$ & 4426 a & 4046 a \\
\hline & N1 mean & 7162 & 6254 & 5340 & 4407 & 4079 & 4313 \\
\hline \multirow[t]{4}{*}{$\mathrm{N} 2$} & $\mathrm{TF}$ & $8135 \mathrm{a}$ & $6717 \mathrm{a}$ & $6712 \mathrm{a}$ & $5047 \mathrm{c}$ & 4862 a & $4368 \mathrm{a}$ \\
\hline & PM & $7978 \mathrm{a}$ & $6777 \mathrm{a}$ & $6509 \mathrm{a}$ & $5253 \mathrm{~b}$ & 4448 a & $3833 \mathrm{a}$ \\
\hline & SM & $7042 \mathrm{a}$ & $6593 \mathrm{a}$ & $4219 \mathrm{~b}$ & $5963 \mathrm{a}$ & 4480 a & $5129 \mathrm{a}$ \\
\hline & N2 mean & 7718 & 6696 & 5813 & 5421 & 4597 & 4443 \\
\hline \multirow[t]{5}{*}{ N3 } & $\mathrm{TF}$ & $7892 \mathrm{a}$ & 7096 a & 5892 a & $4584 \mathrm{a}$ & $4838 \mathrm{a}$ & 4399 a \\
\hline & PM & 7959 a & $6943 \mathrm{a}$ & $6921 \mathrm{a}$ & $4769 \mathrm{a}$ & $4144 \mathrm{a}$ & $4311 \mathrm{a}$ \\
\hline & SM & 7196 a & $6872 \mathrm{a}$ & $5812 \mathrm{a}$ & $4861 \mathrm{a}$ & $4364 \mathrm{a}$ & $4275 \mathrm{a}$ \\
\hline & $\mathrm{N} 3$ mean & 7682 & 6970 & 6209 & 4738 & 4449 & 4328 \\
\hline & $\operatorname{LSD}_{0.05}{ }^{\mathrm{d}}$ & 540 & 294 & 734 & 87 & 291 & 606 \\
\hline
\end{tabular}

Within each column, values with the same letters are not significantly different by LSD at the 0.05 level across all fertilizer $\mathrm{N}$ rates.

${ }^{a} \mathrm{~N} 0$ : no fertilizer $\mathrm{N}$ for either rice or wheat; $\mathrm{N} 1: 75 \mathrm{~kg} \mathrm{~N} \mathrm{ha}^{-1}$ for rice and $60 \mathrm{~kg} \mathrm{~N} \mathrm{ha}^{-1}$ for wheat; $\mathrm{N} 2: 150 \mathrm{~kg} \mathrm{~N} \mathrm{ha}{ }^{-1}$ for rice and $120 \mathrm{~kg} \mathrm{~N} \mathrm{ha}^{-1}$ for wheat; N3: $225 \mathrm{~kg} \mathrm{~N} \mathrm{ha}^{-1}$ for rice and $180 \mathrm{~kg} \mathrm{~N} \mathrm{ha}^{-1}$ for wheat.

b TF: traditional flooding; PM: plastic film mulching; SM: wheat straw mulching represent.

${ }^{\mathrm{c}}$ Mean crop yield for each fertilizer $\mathrm{N}$ rate across all three cultivation systems.

${ }^{\mathrm{d}} \mathrm{LSD}_{0.05}$ value for comparison among the four $\mathrm{N}$ rate mean values across all three cultivation systems.

$\mathrm{N} 1$ or $\mathrm{N} 3$, and a significant difference in wheat yields between $\mathrm{N} 2$ and $\mathrm{N} 1$ or $\mathrm{N} 3$ levels was observed in the 2000/2001 and 2001/2002 wheat seasons. Overall, crops responded to fertilizer $\mathrm{N}$ rates up to $\mathrm{N} 2$, but with no further response to additional applied N (N3).

\subsubsection{Effects of non-flooded mulching cultivation on rice and wheat grain yields}

Table 1 also lists the rice and wheat grain yields in different mulching cultivation systems. Under NO and $\mathrm{N} 1$, in comparison to TF, rice grain yields under PM showed an increased trend and significant differences occurred in the 2000 and 2001 seasons. Rice grain yields under SM were lower than in TF in the 2000 and 2002 seasons and similar to TF in the 2001 season. Under N2 and N3, there were no significant differences among the three systems in every season except 2002. Over the 3 years, average rice grain yields under PM increased by $14 \%$ and $2 \%$ with the lower N levels (N0 and N1) and higher levels (N2 and $\mathrm{N} 3$ ), respectively, while those under SM decreased by $16 \%$ and $4.7 \%$ compared with TF.
Under N0, wheat grain yields using SM were higher than those using PM and/or TF, with significant differences observed in the 2000/2001 and 2001/2002 seasons. In comparison to TF, the average wheat grain yields using SM increased by $18 \%$. Clearly, wheat straw mulching (SM) of the preceding rice crop had a residual effect on the succeeding wheat. There were no clearly different trends in wheat grain yields between $\mathrm{PM}$ and TF over the 3 years, suggesting that plastic film mulching in the preceding rice season had no effect on the succeeding wheat.

\subsubsection{Total system productivity}

Total annual and mean system productivity for rice-wheat rotations as affected by $\mathrm{N}$ rate and nonflooded mulching cultivation are presented in Table 2. System productivity for individual treatments and years ranged widely from 6.9 to $9.1 \mathrm{t} \mathrm{ha}^{-1}$ under NO and from 9.3 to $13.2 \mathrm{t} \mathrm{ha}^{-1}$ under $\mathrm{N} 2$ over the 3 -year period, and the 3 -year mean value across treatments ranged from 7.8 to $8.7 \mathrm{t} \mathrm{ha}^{-1}$ under $\mathrm{N} 0$ and from 11.1 to $11.9 \mathrm{t} \mathrm{ha}^{-1}$ under $\mathrm{N} 2$. In general, mean system 
Table 2

Annual and 3-year mean total system productivity ${ }^{\mathrm{a}}$ under two fertilizer $\mathrm{N}$ rates for rice-wheat rotations on Chengdu Plain, southwest China $\left(\mathrm{kg} \mathrm{ha}^{-1}\right)$

\begin{tabular}{|c|c|c|c|c|c|}
\hline$\overline{N \text { rate }^{b}}$ & Cultivation system $^{\mathrm{c}}$ & $2000 / 2001$ & $2001 / 2002$ & $2002 / 2003$ & Three-year mean \\
\hline \multirow[t]{3}{*}{ NO } & TF & 8226 & 8121 & 7399 & 7915 \\
\hline & PM & 9180 & 8746 & 8174 & 8700 \\
\hline & SM & 7372 & 9073 & 6984 & 7810 \\
\hline \multirow[t]{3}{*}{$\mathrm{N} 2$} & $\mathrm{TF}$ & 13182 & 11543 & 11080 & 11935 \\
\hline & PM & 13230 & 11224 & 10342 & 11599 \\
\hline & SM & 13005 & 11073 & 9348 & 11142 \\
\hline
\end{tabular}

${ }^{\mathrm{a}}$ Total system productivity indicates combined grain yields of rice and wheat.

b N0: no fertilizer $\mathrm{N}$ for either rice or wheat; $\mathrm{N} 2: 150 \mathrm{~kg} \mathrm{~N} \mathrm{ha}^{-1}$ for rice and $120 \mathrm{~kg} \mathrm{~N} \mathrm{ha}^{-1}$ for wheat.

${ }^{c}$ TF: traditional flooding; PM: plastic film mulching; SM: wheat straw mulching.

productivity followed the sequence of $\mathrm{PM}>\mathrm{TF}>\mathrm{SM}$ under N0 and of TF $>$ PM $>$ SM under N2. Across years and treatments, system productivity was greater under $\mathrm{N} 2$ than under $\mathrm{N} 0$.

\subsection{Nitrogen uptake by rice and wheat}

Non-flooded mulching cultivation significantly affected crop $\mathrm{N}$ uptake as shown in Table 3. Compared with TF or PM, average N uptake by rice using SM $\left(78 \mathrm{~kg} \mathrm{ha}^{-1}\right.$ in 2000, $94 \mathrm{~kg} \mathrm{ha}^{-1}$ in 2001, and $81 \mathrm{~kg} \mathrm{ha}^{-1}$ in 2002) decreased significantly, while average $\mathrm{N}$ uptake by wheat using SM showed an increasing trend in 2000/2001 and 2002/2003 seasons $\left(113 \mathrm{~kg} \mathrm{ha}^{-1}\right.$ in $2000 / 2001$ and $95 \mathrm{~kg} \mathrm{ha}^{-1}$ in 2002/ 2003 season), and significant differences were observed in the 2000/2001 season. N uptake by wheat followed patterns similar to wheat biomass yield (data

Table 3

Effects of non-flooded mulching cultivation and fertilizer $\mathrm{N}$ rate on $\mathrm{N}$ uptake by rice and wheat in rice-wheat rotations on Chengdu Plain, southwest China $\left(\mathrm{kg} \mathrm{ha}^{-1}\right)$

\begin{tabular}{|c|c|c|c|c|c|c|c|}
\hline \multirow[t]{2}{*}{ Cultivation system ${ }^{\mathrm{a}}$} & \multirow[t]{2}{*}{$\mathrm{N}$ rate $^{\mathrm{b}}$} & \multicolumn{3}{|l|}{ Rice } & \multicolumn{3}{|l|}{ Wheat } \\
\hline & & 2000 & 2001 & 2002 & $2000 / 2001$ & $2001 / 2002$ & $2002 / 2003$ \\
\hline \multirow[t]{5}{*}{$\mathrm{TF}$} & No & $60 \mathrm{c}$ & $65 \mathrm{c}$ & $75 \mathrm{~b}$ & $55 \mathrm{~d}$ & $59 \mathrm{c}$ & $54 \mathrm{~b}$ \\
\hline & N1 & $92 \mathrm{~b}$ & $82 \mathrm{bc}$ & $100 \mathrm{ab}$ & $86 \mathrm{c}$ & $92 \mathrm{~b}$ & $79 \mathrm{ab}$ \\
\hline & $\mathrm{N} 2$ & $136 \mathrm{a}$ & $98 \mathrm{~b}$ & $129 \mathrm{ab}$ & $126 \mathrm{a}$ & $106 \mathrm{~b}$ & $92 \mathrm{ab}$ \\
\hline & N3 & $141 \mathrm{a}$ & $130 \mathrm{a}$ & $140 \mathrm{a}$ & $116 \mathrm{~b}$ & $131 \mathrm{a}$ & 98 a \\
\hline & TF mean ${ }^{c}$ & 110 & 94 & 111 & 96 & 97 & 81 \\
\hline \multirow[t]{5}{*}{ PM } & N0 & $60 \mathrm{c}$ & $80 \mathrm{c}$ & $78 \mathrm{~b}$ & $62 \mathrm{c}$ & $47 \mathrm{c}$ & $62 \mathrm{~b}$ \\
\hline & N1 & $81 \mathrm{~b}$ & $95 \mathrm{bc}$ & $104 \mathrm{ab}$ & $92 \mathrm{~b}$ & $73 \mathrm{~b}$ & $76 \mathrm{ab}$ \\
\hline & $\mathrm{N} 2$ & $103 \mathrm{a}$ & $113 \mathrm{~b}$ & $118 \mathrm{a}$ & $134 \mathrm{a}$ & 96 a & $85 \mathrm{ab}$ \\
\hline & N3 & $114 \mathrm{a}$ & 138 a & $140 \mathrm{a}$ & 129 a & $105 \mathrm{a}$ & $106 \mathrm{a}$ \\
\hline & PM mean & 89 & 106 & 110 & 104 & 80 & 82 \\
\hline \multirow[t]{6}{*}{ SM } & N0 & $48 \mathrm{~b}$ & $75 \mathrm{c}$ & $51 \mathrm{~b}$ & $61 \mathrm{c}$ & $64 \mathrm{~b}$ & $67 \mathrm{~b}$ \\
\hline & N1 & $65 \mathrm{~b}$ & $82 \mathrm{bc}$ & $77 \mathrm{~b}$ & $99 \mathrm{~b}$ & 90 a & $77 \mathrm{~b}$ \\
\hline & $\mathrm{N} 2$ & $101 \mathrm{a}$ & $97 \mathrm{~b}$ & $79 \mathrm{~b}$ & $152 \mathrm{a}$ & $110 \mathrm{a}$ & $120 \mathrm{a}$ \\
\hline & N3 & 97 a & $122 \mathrm{a}$ & $118 \mathrm{a}$ & $140 \mathrm{a}$ & $108 \mathrm{a}$ & $117 \mathrm{a}$ \\
\hline & SM mean & 78 & 94 & 81 & 113 & 93 & 95 \\
\hline & $\mathrm{LSD}_{0.05}{ }^{\mathrm{d}}$ & 10 & 7 & 18 & 7 & 10 & 15 \\
\hline
\end{tabular}

Within each column, values with the same letters are not significantly different by LSD at the 0.05 level across all cultivation systems.

a TF: traditional flooding; PM: plastic film mulching; SM: wheat straw mulching.

b $\mathrm{N} 0$ : no fertilizer $\mathrm{N}$ for either rice or wheat; $\mathrm{N} 1: 75 \mathrm{~kg} \mathrm{~N} \mathrm{ha}^{-1}$ for rice and $60 \mathrm{~kg} \mathrm{~N} \mathrm{ha}^{-1}$ for wheat; $\mathrm{N} 2: 150 \mathrm{~kg} \mathrm{~N} \mathrm{ha}^{-1}$ for rice and $120 \mathrm{~kg} \mathrm{~N} \mathrm{ha}^{-1}$ for wheat; N3: $225 \mathrm{~kg} \mathrm{~N} \mathrm{ha}^{-1}$ for rice and $180 \mathrm{~kg} \mathrm{~N} \mathrm{ha}^{-1}$ for wheat.

${ }^{\mathrm{c}}$ The mean $\mathrm{N}$ uptake by crops in each mulching system across four fertilizer $\mathrm{N}$ rates.

${ }^{\mathrm{d}} \mathrm{LSD}_{0.05}$ value for comparison among the three cultivation system mean values across all four fertilizer $\mathrm{N}$ rates. 
not shown). No obvious difference was observed between PM and TF in average $\mathrm{N}$ uptake by either rice or wheat.

Crop $\mathrm{N}$ uptake increased with increasing $\mathrm{N}$ application rate. However, crop $\mathrm{N}$ uptakes under N3 were higher than, or similar to those under N2, with the exception of TF in the 2000/2001 season (126 kg ha ${ }^{-1}$ under $\mathrm{N} 2$ and $116 \mathrm{~kg} \mathrm{ha}^{-1}$ under N3). This suggest that $\mathrm{N}$ inputs above $150 \mathrm{~kg} \mathrm{~N}^{-1}$ in the rice season and $120 \mathrm{~kg} \mathrm{Nha}^{-1}$ in the wheat season may have resulted in luxury uptake of $\mathrm{N}$ by the crops in view of the crop yield response up to N2.

\subsection{Residual soil $N_{\min }$}

\subsubsection{Effects of $N$ rate on residual soil $N_{\min }$}

Values of residual soil $\mathrm{N}_{\text {min }}$ from the top $60 \mathrm{~cm}$ of the soil profile as influenced by $\mathrm{N}$ rate are presented in Fig. 2. Statistical analysis indicates that $\mathrm{N}$ rate significantly affected residual soil $\mathrm{N}_{\min }$ after the wheat harvest. Residual soil $\mathrm{N}_{\text {min }}$ increased with $\mathrm{N}$ fertilizer application. Significant differences were observed between N0 or N1 and N2 or N3 over the 3year period. However, during the 2000 and 2002 seasons, no differences were observed among the four $\mathrm{N}$ rates after the rice harvest, but during the 2001 season $\mathrm{N} 3$ was similar to $\mathrm{N} 2$ and much lower than $\mathrm{N} 1$ or N0, presumably because of luxury uptake of $\mathrm{N}$ by rice under N3 (Table 4).

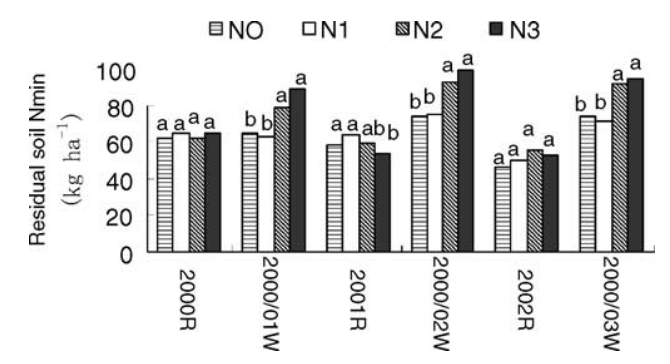

Fig. 2. Effects of fertilizer $N$ rate on residual $N_{\text {min }}$ in $0-60 \mathrm{~cm}$ soil (average of three cultivation systems) after harvest of rice (R) and wheat $(\mathrm{W})$ during three cycles of rice-wheat rotation. Values with the same letter in a group are not significantly different by LSD at the 0.05 level. N0, no fertilizer $\mathrm{N}$ for either rice or wheat; $\mathrm{N} 1$, $75 \mathrm{~kg} \mathrm{~N} \mathrm{ha}^{-1}$ for rice and $60 \mathrm{~kg} \mathrm{~N} \mathrm{ha}^{-1}$ for wheat; N2, $150 \mathrm{~kg} \mathrm{~N}$ $\mathrm{ha}^{-1}$ for rice and $120 \mathrm{~kg} \mathrm{~N}^{-1}$ for wheat; N3, $225 \mathrm{~kg} \mathrm{~N}^{-1}$ for rice and $180 \mathrm{~kg} \mathrm{~N} \mathrm{ha}^{-1}$ for wheat.
Table 4

Effects of non-flooded mulching cultivation on $\mathrm{N}$ forms of residual soil $\mathrm{N}_{\min }$ in rice-wheat rotations on Chendu Plain, southwest China $\left(\mathrm{kg} \mathrm{ha}^{-1}\right)$

\begin{tabular}{|c|c|c|c|c|c|c|}
\hline \multirow{2}{*}{$\begin{array}{l}\text { Cultivation } \\
\text { system }^{\text {a }}\end{array}$} & \multicolumn{3}{|l|}{ Rice } & \multicolumn{3}{|l|}{ Wheat } \\
\hline & 2000 & 2001 & 2002 & $2000 / 2001$ & $2001 / 2002$ & $2002 / 2003$ \\
\hline \multicolumn{7}{|l|}{$\mathrm{NH}_{4}-\mathrm{N}$} \\
\hline $\mathrm{TF}$ & $55 \mathrm{a}$ & $45 \mathrm{a}$ & $33 \mathrm{a}$ & $54 \mathrm{a}$ & $38 \mathrm{a}$ & $46 \mathrm{a}$ \\
\hline PM & $55 \mathrm{a}$ & $36 \mathrm{~b}$ & $21 \mathrm{~b}$ & $41 \mathrm{~b}$ & $31 \mathrm{a}$ & $45 \mathrm{a}$ \\
\hline SM & $57 \mathrm{a}$ & $33 \mathrm{~b}$ & $21 \mathrm{~b}$ & $50 \mathrm{a}$ & $39 \mathrm{a}$ & $44 \mathrm{a}$ \\
\hline \multicolumn{7}{|l|}{$\mathrm{NO}_{3}-\mathrm{N}$} \\
\hline $\mathrm{TF}$ & $8 \mathrm{a}$ & $10 \mathrm{c}$ & $21 \mathrm{~b}$ & $30 \mathrm{a}$ & $50 \mathrm{a}$ & $42 a$ \\
\hline PM & $7 \mathrm{a}$ & $30 \mathrm{a}$ & $29 \mathrm{a}$ & $23 \mathrm{a}$ & $51 \mathrm{a}$ & $37 \mathrm{a}$ \\
\hline SM & $8 \mathrm{a}$ & $24 \mathrm{~b}$ & $29 \mathrm{a}$ & $24 \mathrm{a}$ & $49 a$ & $39 \mathrm{a}$ \\
\hline
\end{tabular}

Within each column, values with the same letters are not significantly different by LSD at 0.05 level across all cultivation systems.

${ }^{\text {a }}$ TF: traditional flooding; PM: plastic film mulching; SM: wheat straw mulching.

\subsubsection{Effects of non-flooded mulching cultivation on residual soil $N_{\min }$}

The amounts of residual soil $\mathrm{N}_{\min }$ from $0-60 \mathrm{~cm}$ after the wheat harvest were consistently higher than those after the rice harvest over the 3-year period (Fig. 3). Residual soil $\mathrm{N}_{\min }$ after the rice harvest ranged from 50 to $65 \mathrm{~kg} \mathrm{ha}^{-1}$ and was unaffected by either PM or SM treatments. Residual soil $\mathrm{N}_{\text {min }}$ after the wheat harvest ranged from 82 to $88 \mathrm{~kg} \mathrm{ha}^{-1}$ throughout both the 2001/2002 and 2002/2003 seasons, and was not influenced by the experimental treatments. During the 2000/2001 season PM was

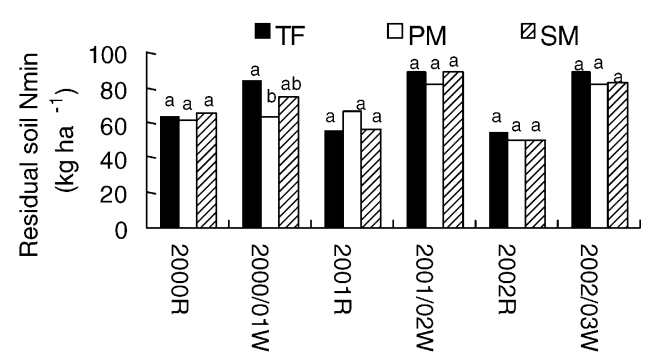

Fig. 3. Effects of non-flooded mulching cultivation on residual Nmin in $0-60 \mathrm{~cm}$ soil (average of four $\mathrm{N}$ rates) after harvest of rice $(\mathrm{R})$ and wheat $(\mathrm{W})$ during three cycles of rice-wheat rotation. Values with the same letter in a group are not significantly different by LSD at the 0.05 level. TF: traditional flooding; PM: plastic film mulching; SM: wheat straw mulching. 
Table 5

Effects of non-flooded mulching cultivation and fertilizer $\mathrm{N}$ rate on the net $\mathrm{N}$ balance $\left(\mathrm{kg} \mathrm{ha}^{-1}\right)$ in rice-wheat rotations on Chengdu Plain, southwest China (2000-2003)

\begin{tabular}{|c|c|c|c|c|c|c|c|}
\hline \multirow[t]{2}{*}{ Cultivation systems ${ }^{\mathrm{a}}$} & \multirow[t]{2}{*}{$\mathrm{N}$ rate } & \multicolumn{4}{|l|}{ Input } & \multirow[t]{2}{*}{ Removal by crops ${ }^{\mathrm{c}}(E)$} & \multirow[t]{2}{*}{ Net $\mathrm{N}$ balance ${ }^{\mathrm{d}}(F)$} \\
\hline & & Fertilizer $(A)$ & Straw $(B)$ & Rainfall $(C)$ & Irrigation $^{\mathrm{b}}(D)$ & & \\
\hline \multirow[t]{4}{*}{$\mathrm{TF}$} & No & 0 & 0 & 25 & 16 & 368 & -327 \\
\hline & N1 & 405 & 0 & 25 & 16 & 531 & -85 \\
\hline & $\mathrm{N} 2$ & 810 & 0 & 25 & 16 & 687 & 164 \\
\hline & N3 & 1215 & 0 & 25 & 16 & 756 & 500 \\
\hline \multirow[t]{4}{*}{ PM } & No & 0 & 0 & 25 & 4 & 389 & -360 \\
\hline & N1 & 405 & 0 & 25 & 4 & 521 & -87 \\
\hline & $\mathrm{N} 2$ & 810 & 0 & 25 & 4 & 679 & 160 \\
\hline & N3 & 1215 & 0 & 25 & 4 & 732 & 512 \\
\hline \multirow[t]{4}{*}{ SM } & No & 0 & 79 & 25 & 4 & 366 & -258 \\
\hline & N1 & 405 & 79 & 25 & 4 & 490 & 23 \\
\hline & $\mathrm{N} 2$ & 810 & 79 & 25 & 4 & 659 & 259 \\
\hline & N3 & 1215 & 79 & 25 & 4 & 702 & 621 \\
\hline
\end{tabular}

\footnotetext{
${ }^{\text {a }}$ TF: traditional flooding; PM: plastic film mulching; SM: wheat straw mulching.

${ }^{\mathrm{b}} \mathrm{N}$ input through irrigation water are estimated with average inorganic $\mathrm{N}$ concentration of irrigation water in 2003 rice season $(n=9)$ by total amount of irrigation water during three experimental years.

$\mathrm{c}$ The total $\mathrm{N}$ uptake by rice and wheat during three rotation period.

${ }^{\mathrm{d}} F=A+B+C+D-E$.
}

much lower than TF, but there is no clear explanation for this.

Across the years, residual soil $\mathrm{N}_{\min }$ values were usually higher in the surface $0-20 \mathrm{~cm}$ layer than in the lower depths irrespective of treatment (data not shown). This may be due to higher soil organic $\mathrm{N}$ levels and more favourable conditions for mineralization and nitrification in the top $20 \mathrm{~cm}$ of soil than in the deeper layers (Hadas et al., 1986; Sahrawat, 1983).

\subsubsection{Extractable soil $\mathrm{NH}_{4}-\mathrm{N}$ and $\mathrm{NO}_{3}-\mathrm{N}$}

Table 4 lists the extractable soil $\mathrm{NH}_{4}-\mathrm{N}_{\text {and }} \mathrm{NO}_{3}-\mathrm{N}$ after each crop harvest in the three cultivation systems. The extractable soil $\mathrm{NH}_{4}-\mathrm{N}$ and $\mathrm{NO}_{3}-\mathrm{N}$ after the rice harvest was greatly influenced by non-flooded mulching cultivation. After the rice harvest in the 2001 and 2002 seasons, the extractable soil $\mathrm{NH}_{4}-\mathrm{N}$ under TF was significantly higher than under PM and SM. In contrast, soil $\mathrm{NO}_{3}-\mathrm{N}$ under PM and $\mathrm{SM}$ was significantly higher than under TF. This was likely to be because non-flooding mulching cultivations favour aerobic $\mathrm{N}$ transformations, resulting in nitrification of $\mathrm{NH}_{4}-\mathrm{N}$ to $\mathrm{NO}_{3}-\mathrm{N}$. There were no statistical differences in extractable soil $\mathrm{NH}_{4}-\mathrm{N}$ and $\mathrm{NO}_{3}-\mathrm{N}$ after the wheat harvest among the three cultivation systems over three experimental years, with the sole exception of $\mathrm{NH}_{4}-\mathrm{N}$ in 2000/2001 season.

\subsection{Net $N$ balance}

The net $\mathrm{N}$ balances in the three cultivation systems with four $\mathrm{N}$ rates are presented in Table 5 . Net $\mathrm{N}$ balance ranged widely from -360 to $621 \mathrm{~kg} \mathrm{ha}^{-1}$, and was related mainly to the applied $\mathrm{N}$ rate over the treatments. In the higher $\mathrm{N}$ treatments $(\mathrm{N} 2$ and N3), the net $\mathrm{N}$ balances were 164,160 and $259 \mathrm{~kg} \mathrm{ha}^{-1}$ for TF, PM and SM under N2, and 500, 512 and $621 \mathrm{~kg} \mathrm{ha}^{-1}$ for TF, PM and SM under N3, respectively. In contrast, in the $0 \mathrm{~kg} \mathrm{~N} \mathrm{ha}^{-1}$ (N0) and $135 \mathrm{~kg} \mathrm{~N}^{-1}$ (N1) treatments the total $\mathrm{N}$ outputs were consistently higher than the $\mathrm{N}$ inputs, with the exception of $\mathrm{N} 1$ under SM. This resulted in a negative balance, ranging from -360 to $-85 \mathrm{~kg} \mathrm{ha}^{-1}$.

In comparison to $\mathrm{TF}, \mathrm{SM}$ led to a higher net $\mathrm{N}$ balance due to the additional input from wheat straw as mulching material and the lower $\mathrm{N}$ removal by crops across the $\mathrm{N}$ treatments. However, there were no clear difference found between PM and TF in the net $\mathrm{N}$ balance.

\section{Discussion}

Our results demonstrate the interactive effects of non-flooded mulching cultivation and $\mathrm{N}$ rate on crop 
yield, system productivity, crop $\mathrm{N}$ uptake and $\mathrm{N}$ cycling. Moreover, despite year-to-year variations in climatic conditions, these effects were remarkably consistent.

Non-flooded mulching cultivation for rice, a new water-saving technology, greatly reduced the duration of soil submergence. In the six consecutive cropping seasons from May 2000 to 2003, the soil was submerged for $30 \%$ of the time in TF systems and only $10 \%$ in the non-flooded mulching cultivation systems. These differences in hydrological status had large effects on crop yields and system productivity under low $\mathrm{N}$ rates (N0 and $\mathrm{N} 1$ ), but relatively small effects under high $\mathrm{N}$ rates (N2 and N3). On the other hand, crop yield, $\mathrm{N}$ uptake and net $\mathrm{N}$ balance were quite sensitive to $\mathrm{N}$ rate during the experimental period.

\subsection{Crop yields and system productivity}

Significant grain yield responses to $\mathrm{N}$ fertilization were evident during the 3-year period (Table 1). However, $\mathrm{N}$ application rates above $150 \mathrm{~kg} \mathrm{~N} \mathrm{ha}^{-1}$ for rice and $120 \mathrm{~kg} \mathrm{~N} \mathrm{ha}^{-1}$ for wheat (N2) led to increased crop $\mathrm{N}$ uptake (Table 3) and $\mathrm{N}$ balance surplus (Table 5) without a corresponding increase in grain yield in the three systems. Other studies in China have also shown that both wheat and rice may attain higher yields when fertilizer $\mathrm{N}$ (from 120 to $150 \mathrm{~kg} \mathrm{~N} \mathrm{ha}^{-1}$ ) is combined with suitable $\mathrm{P}$ and/or $\mathrm{K}$ applications (Zhu, 1999). In some long-term rice-wheat experiments in India, the recommended $\mathrm{N}$ application rate $\left(120 \mathrm{~kg} \mathrm{Nha}^{-1}\right.$ for both rice and wheat) either reduced the rate of yield decline or reversed the trend (Yadav et al., 2000). However, NPK fertilizer applied once as a basal application during the rice season in the present study would not be conducive to efficient use of nutrients (especially $\mathrm{N}$ ) and would need to be modified on the basis of further studies on rice-wheat rotations.

The $14 \%$ increase in rice grain yield in PM and the $16 \%$ decrease in rice grain yield in SM under lower $\mathrm{N}$ levels (N0 and N1) compared with TF may be ascribed mainly to temperature differences in the surface soil in the three cultivation systems at early growth stages of rice. PM increased the daily mean temperature of surface soil and seasonal cumulative heat units, but soil temperatures in SM were much lower than in TF or PM (Liu et al., 2003; Peng et al., 1999; Parker and Larson, 1962). Higher temperatures are favourable for $\mathrm{N}$ mineralization (Wilson and Jefferies, 1996; Bernhard-Reversat, 1988) and enhance plant N uptake (Liu and Muller, 1993). Thus, $\mathrm{N}$ deficiency as a result of zero or inadequate $\mathrm{N}$ fertilizer may be alleviated. In addition, Shen et al. (1997) reported that plastic film mulching cultivation produced larger and more vigorous root systems and increased early tillering of rice due to higher temperatures. Thus, PM attained higher rice yields than TF and SM. Lower temperatures of surface soil and $\mathrm{N}$ immobilization caused by the initial degradation of wheat residues in the SM treatment, however, may contribute to lowered available $\mathrm{N}$ for rice and therefore decreases in rice yield and N uptake (Rao and Mikkelsen, 1976; Jenkinson, 1985; Liu et al., 2003).

Under N2 and N3, N was not a factor limiting rice growth at early stages as large quantities of fertilizer $\mathrm{N}$ were applied. As a result, the effect of $\mathrm{N}$ mineralization resulting from different temperatures on plant available $\mathrm{N}$ may be negligible. Thus, the three cultivation systems produced similar yields. Previous studies have also indicated that rice yields in mulching cultivation, including plastic film mulching and crop straw mulching, were higher than or similar to those in traditional flooded cultivation (Liang et al., 1999; Wu et al., 1999; Fan et al., 2002). However, the present study does not support the findings of Liu et al. (2003) that SM decreased rice yield under N2, compared with TF. At present, the different trends in the two studies cannot be explained.

Wheat yields did not differ significantly between $\mathrm{PM}$ and TF. However, wheat straw mulching (SM) in the preceding rice season had a residual effect on succeeding wheat as evidenced by the higher wheat yield in SM than in PM or TF under N0. The larger fraction of wheat straw remaining in the soil by the end of the rice crop is likely to decompose during the wheat season and may determine residual effects on $\mathrm{N}$ supply capacity and soil productivity. Eagle et al. (2000) reported that rice yields in zero-N plots in which rice straw was retained by incorporation and rolling were greater by the third year of the experiment compared with other treatments such as burning and removal of rice straw. A treatment in which straw was applied surpassed a zero-fertilizer treatment in both $\mathrm{N}$ uptake and yield by the second season in a study 
conducted in the Philippines (Becker et al., 1994). Aulakh et al. (2000) also reported residual effects of green manure on wheat yields in rice-wheat rotations.

System productivity (combined grain yields of rice and wheat) under PM was similar to that in TF across $\mathrm{N}$ treatments. In contrast, system productivity under SM was consistently lower than in the TF and PM treatments. Such trends may be ascribed to the effect of decreasing rice yields in SM.

\subsection{Net $N$ balance and residual soil $N_{\min }$}

The $\mathrm{N}$ balance may have been largely influenced by $\mathrm{N}$ losses and $\mathrm{N}$ inputs that were not measured directly. In the present study, higher $\mathrm{N}$ inputs (N2 and N3) led to higher $\mathrm{N}$ balance surplus, while low $\mathrm{N}$ inputs ( $\mathrm{N} 0$ and N1) resulted in balance deficits. This indicates that fertilizer $\mathrm{N}$ losses occurred mainly under higher fertilizer inputs, and this pattern was less pronounced under non-flooded mulching cultivation.

Among the three cultivation systems, SM led to the highest net $\mathrm{N}$ balance. Similar result has been reported by Liu et al. (2003) in R-W systems. Retention of straw on the surface also increased soil nitrate concentrations, $\mathrm{N}$ uptake, and yield compared to burning (Bacon, 1987; Bacon and Cooper, 1985a,b). Thus, SM may be a good option from the viewpoint of $\mathrm{N}$ balance and soil fertility. There are often concerns about increased greenhouse gas emissions (e.g. $\mathrm{N}_{2} \mathrm{O}$ and $\mathrm{CH}_{4}$ ) when straw is returned to the soil (Bronson et al., 1997), but burning rice straw releases amounts of both $\mathrm{N}_{2} \mathrm{O}$ and $\mathrm{CH}_{4}$ comparable with those from decomposing straw (Yoshinori and Kanno, 1997). In this context, there was no clear difference found in net $\mathrm{N}$ balance between TF and PM. However, the $\mathrm{N}$ balance was underestimated, especially under $\mathrm{TF}$ conditions, due to input from biological $\mathrm{N}_{2}$ fixation was not accounted for. In the non-flooded cultivation system, $\mathrm{N}$ inputs from biological $\mathrm{N}_{2}$ fixation may be small because it is generally thought the well-aerated soil lead to relatively small biological $\mathrm{N}_{2}$ fixation (Bohlool et al., 1992; Kennedy and Tchan, 1997).

Soil mineral $\mathrm{N}$ in the top $60 \mathrm{~cm}$ of the soil after the rice harvest was less affected by non-flooded mulching cultivation and $\mathrm{N}$ rate, ranging from 50 to $65 \mathrm{~kg} \mathrm{ha}^{-1}$ over treatments and years. This may be ascribed to large $\mathrm{N}$ losses occurring in the rice season (Ai, 2003). However, the primary $\mathrm{N}$ loss pathways are likely to have differed among the three cultivation systems. Although $\mathrm{N}$ losses due to leaching cannot be ruled out in the present experiment, most gaseous $\mathrm{N}$ losses in TF appear to be due to ammonia volatilization (Fillery and De Datta, 1986; Zhu, 1997). Midseason aeration in $\mathrm{TF}$, which is practiced widely in the Chengdu plain, resulted in increased $\mathrm{N}_{2} \mathrm{O}$ emission (Cai et al., 1999; Yan et al., 2000) and this may also be responsible for gaseous $\mathrm{N}$ losses. The present study does not indicate the lower $\mathrm{N}$ loss resulting from reducing ammonia volatilization that we would expect to find under non-flooded mulching cultivation. Our interpretation is that non-flooded mulching cultivation systems are almost equivalent to rain fed lowland rice fields in which erratic rainfall can lead to alternate cycles of soil drying and wetting during the rice growing period thereby enhancing $\mathrm{N}$ losses through nitrification-denitrification (Buresh and De Datta, 1990; Abao et al., 2000). The higher $\mathrm{NO}_{3}-\mathrm{N}$ accumulation after rice harvest under PM and SM than that under TF appears to confirm this interpretation (Table 4). Dittert et al. (2002) and Li et al. (2003) also found that non-flooded mulching rice cultivation increased $\mathrm{N}_{2} \mathrm{O}$ emissions, and these emissions were closely linked to $\mathrm{N}$ fertilizer application events.

On the other hand, a larger $\mathrm{N}$ accumulation after the wheat harvest than after the rice harvest was observed, which increased with increasing fertilizer $\mathrm{N}$ application. Average $\mathrm{NO}_{3}-\mathrm{N}$ content across cultivation systems ranged from 23 to $51 \mathrm{~kg} \mathrm{ha}^{-1}$, accounting for about $32-62 \%$ of residual $\mathrm{N}_{\min }$. Buresh et al. (1989) reported $\mathrm{NO}_{3}-\mathrm{N}$ levels of $39-91 \mathrm{~kg} \mathrm{~N}^{-1}$ in the top $60 \mathrm{~cm}$ soil layer at onset of the wet season in a mungbean/lowland rice systems in the Philippines. The evidence indicates, however, that large amounts of accumulated soil $\mathrm{NO}_{3}{ }^{-}-\mathrm{N}$ during the wheat season may be lost from rice lowlands upon the flooding of aerobic soil for rice production (Buresh et al., 1989; George et al., 1992; Ladha et al., 2000). Achievement of efficient use of $\mathrm{N}$ by the whole system requires that the wheat crop leave as little mineral $\mathrm{N}$ as possible at the end of the season.

\section{Conclusions}

The present study shows that crops responded to fertilizer $\mathrm{N}$ rates up to $\mathrm{N} 2\left(150 \mathrm{~kg} \mathrm{ha}^{-1} \mathrm{~N}\right.$ for rice and 
$120 \mathrm{~kg} \mathrm{ha}^{-1} \mathrm{~N}$ for wheat) in three cultivation systems. Under the recommended fertilizer N input (N2), nonflooded mulching cultivation may be utilized as an alternative option for saving water, using efficiently straw and maintaining or improving crop yield in ricewheat rotation systems. Fertilizer $\mathrm{N}$ input as N2, on the other hand, resulted in a trade-off between the positive effects on crop yield (as shown in Table 1) and the negative effect on $\mathrm{N}$ cycling (as shown by increased risk of $\mathrm{N}$ losses). There is, therefore, a need to develop a fertilizer management strategy that ensures an adequate nutrient supply for high and stable overall productivity of rice-wheat rations and sound environmental protection under non-flooded mulching cultivation.

\section{Acknowledgements}

We are grateful to the Major State Basic Research Development Programme of the People's Republic of China (Grant No. G1999011707), the Major Research Programme of the Chinese Ministry of Education (Grant No. 0112), the National Natural Science Foundation of China (Grant Nos. 30390080 and 30370287), and the 863 State High-tech Research Development Project (Grant No. 2002AA6Z3264) for generous financial support.

\section{References}

Abao Jr., E.B., Bronson, K.F., Wassmann, R., Singh, U., 2000. Simultaneous records of methane and nitrous oxide emission in rice-based cropping systems under rainfed conditions. Nutr. Cycling Agroecosyst. 58 (1-3), 131-139.

Ai, Y.W., 2003. Effect of non-flooded mulching cultivation for rice on crop yields and $\mathrm{N}$ fate in rice-wheat cropping systems. Ph.D. Dissertation. China Agricultural University (in Chinese with English abstract), Beijing.

Aulakh, M.S., Khera, T.S., Doran, J.W., Singh, K., Singh, B., 2000. Yields and nitrogen dynamics in a rice-wheat system using green manure and inorganic fertilizer. Soil Sci. Soc. Am. J. 64, 1867-1876.

Bacon, P.E., 1987. Effect of nitrogen fertilization and rice stubble management techniques on soil moisture content, soil nitrogen status, and nitrogen uptake by wheat. Field Crops Res. 17, 75-90.

Bacon, P.E., Cooper, J.L., 1985a. Effect of rice stubble and nitrogen fertilizer management on wheat growth after rice. Field Crops Res. 10, 229-239.
Bacon, P.E., Cooper, J.L., 1985b. Effect of rice stubble and nitrogen fertilizer management techniques on yield of wheat sown after rice. Field Crops Res. 10, 241-250.

Becker, M., Lahda, J.K., Ottow, J.C.G., 1994. Nitrogen losses and lowland rice yield as affected by residue nitrogen release. Soil Sci. Soc. Am. J. 58, 1660-1665.

Bernhard-Reversat, F., 1988. Soil nitrogen mineralization under a Eucalyptus plantation and a natural Acacia forest in Senegal. For. Ecol. Manage. 23, 233-244.

Bohlool, B.B., Ladha, J.K., Garrity, D.P., George, T., 1992. Biological nitrogen fixation for sustainable agriculture: a perspective. Plant Soil 11, 97-100.

Bouman, B.A.M., Tuong, T.P., 2001. Field water management to save water and increase its productivity in irrigated lowland rice. Agric. Water Manage. 49, 11-30.

Bouman, B.A.M., 2001. Water-efficient management strategies in rice production. Int. Rice Res. Notes (IRRN) 26, 17-22.

Bronson, K.F., Neue, H.U., Singh, U., Abao, E.B., 1997. Automated chamber measurements of methane and nitrous oxide flux in a flooded rice soil. I. Residue, nitrogen, and water management. Soil Sci. Soc. Am. J. 61, 981-987.

Buresh, R.J., Woodhead, T., Shepherd, K.D., Flordelis, E.V., Cabangon, R.C., 1989. Nitrate accumulation and loss in a mungbean/ lowland rice cropping system. Soil Sci. Soc. Am. J. 53, 477-482.

Buresh, R.J., De Datta, S.K., 1990. Denitrification losses from puddled rice soils in the tropics. Biol. Fertil. Soils 9, 1-13.

Cai, Z.C., Xing, G.X., Shen, G.Y., Xu, H., Yan, X.Y., Haruo, T., Kazuyuki, Y., Katsuyuki, M., 1999. Measurements of $\mathrm{CH}_{4}$ and $\mathrm{N}_{2} \mathrm{O}$ emission from rice paddies in fengqiu. Chin. Soil Sci. Plant Nutr. 45 (1), 1-13.

Cassman, K.G., Olk, D.C., Dobermann, A., 1997. Scientific evidence of yield and productivity declines in irrigated rice systems of tropical and subtropical Asia. FAO Int. Rice Comm. Newslett. 46, 7-18.

Dittert, K., Lin, S., Kreye, C., Zheng, X.H., Xu, Y.C., Lu, S.J., Huang, Y., Shen, Q.R., Fan, X.L., Sattelmacher, B., 2002. Saving water with ground-cover rice production systems (GCRPS) at the price of increased greenhouse gas emissions? In: Bouman, B.A.M., Hengsdijk, H., Hardy, B., Bindraban, P.S., Tuong, T.P., Ladha, J.K. (Eds.), Proceedings of the International Workshop on Water-wise Rice Production. Los Banos, Philippines, 8-11 April 2002, International Rice Research Institute, Los Banos, Philippines, p. 365.

Dobermann, A., Witt, C., 2000. The potential impact of crop intensification on carbon and nitrogen cycling in intensive rice systems. In: Kirk, G.J.D., Olk, D.C. (Eds.), Proceedings of the International Workshop on Carbon and Nitrogen Dynamics in Flooded Soils. Los Banos, Philippines, 19-22 April 1999, International Rice Research Institute, Makati City, Philippines, p. 188.

Eagle, A.J., Brid, J.A., Horwath, W.R., Linquist, B.A., Brouder, S.M., Hill, J.E., van Kessel, C., 2000. Rice yield and nitrogen utilization efficiency under alternative straw management practices. Agron. J. 92, 1096-1103.

Fan, X.L., Zhang, J.P., Wu, P., 2002. Water and nitrogen use efficiency of lowland rice in ground covering rice production system in south China. J. Plant Nutr. 25, 1855-1862. 
Fillery, I.R.P., De Datta, S.K., 1986. Ammonia volatilization from nitrogen sources applied to rice fields. I. Methodology, ammonia fluxes, and N-15 loss. Soil Sci. Soc. Am. J. 50, 80-86.

George, T., Ladha, J.K., Buresh, R.J., Garrity, D.P., 1992. Managing native and legume-fixed nitrogen in lowland rice-based cropping systems. Plant Soil 141, 69-91.

Guerra, L.C., Bhuiyan, S.L., Tuong, T.P., Baker, R., 1998. Producing more rice with less water. SWIM Paper 5. International Water Management Institute (IWMI), Colombo, Sri Lanka, p. 19.

Hadas, A., Feigenbaum, S., Feigin, A., Portnoy, R., 1986. Nitrogen mineralization in profiles of differently managed soil types. Soil Sci. Soc. Am. J. 50, 314-319.

Hu, F., Yang, M., Liang, Y., Liu, M., Chen, X., 1999. A study on fertility characteristics of paddy soils under plastic film mulching condition. In: Soil Committee of Jiangsu Province (Eds.), Soil Science Towards the 21st Century (Jiangsu Vol.). Hehai University Press, Nanjing (in Chinese).

Jenkinson, D.S., 1985. How straw incorporation affects the nitrogen cycle. In: Hardcastle, J. (Ed.), Straw, Soil and Science. AFRC, London, pp. 14-15.

Kennedy, I.R., Tchan, Y.-T., 1997. Biological nitrogen fixation in non-leguminous field crops: recent advances. Plant Soil 141, 93 118.

Ladha, J.K., Fischer, K.S., Hossain, M., Hobbs, P.R. and Hardy, B., 2000. Improving the productivity and sustainability of ricewheat systems of the Indo-Gangetic Plains: a synthesis of NARS-IRRI partnership research. IRRI Discussion paper 40.

Li, M.L., Xu, Y.C., Shen, Q.R., Zhou, C.L., Yin, J.1., Dittert, K., 2003. The emission of $\mathrm{CH}_{4}$ and $\mathrm{N}_{2} \mathrm{O}$ in aerobic rice field mulched with straw. Chin. Environ. Sci. 23 (6), 579-582 (in Chinese).

Liang, Y.C., Hu, F., Shen, Q.R., Lu, S.H., Wu, L.H., Zhang, F.S., 2000. An overview of rice cultivation on plastic film mulched dryland. In: Feng, F., Zhang, F.S., Yang, X.Q. (Eds.), Studies on Plant Nutrition - Progress and Overview. China Agricultural University Press, Beijing, China, (in Chinese), pp. 114-127.

Liang, Y.C., Hu, F., Yang, M.C., Zhu, X.L., Wang, G.P., Wang, Y.L., 1999. Methods for increasing yield and irrigation water use efficiency of rice using plastic film mulch. Sci. Agric. Sin. 32, 26-32 (in Chinese).

Liu, Y., Muller, R.N., 1993. Aboveground net primary productivity and nitrogen mineralization in a mixed mesophytic forest of eastern Kentuky. For. Ecol. Manage. 59, 53-62.

Liu, X.J., Wang, J.C., Lu, S.H., Zhang, F.S., Zeng, X.Z., Ai, Y.W., Peng, S.B., Christie, P., 2003. Effects of non-flooded mulching cultivation on crop yield, nutrient uptake and nutrient balance in rice-wheat cropping systems. Field Crops Res. 83, 297-311.

Parker, D.T., Larson, W.E., 1962. Nitrification as affected by temperature and moisture content of mulched soils. Soil Sci. Soc. Am. Proc. 26, 238-242.
Peng, S., Shen, K., Wang, X., Liu, J., Luo, X., Wu, L., 1999. A new rice cultivation technology: plastic film mulching. Int. Rice Res. Notes (IRRN) 24, 9-10.

Ponnamperuma, F.N., 1984. Straw as a source of nutrients for wetland rice. Organic Matter and Rice, IRRI, Los Banos, Philippines.

Raison, R.J., 1979. Modification of the soil environment by vegetation fires, with particular reference to nitrogen transformations: a review. Plant Soil 51, 73-108.

Rao, D.N., Mikkelsen, D.S., 1976. Effect of rice straw incorporation on rice plant growth and nutrition. Agron. J. 68, 752-755.

Rasmussen, P.E., Collins, H.P., 1991. Long-term impacts of tillage, fertilizer, and crop residue on soil organic matter in temperate semi-arid regions. Adv. Agron. 45, 93-134.

Sahrawat, K.L., 1983. Mineralization of soil organic nitrogen under waterlogged conditions in relation to other properties of tropical rice soils. Aust. J. Soil. Res. 21, 133-138.

SAS, 1996. SAS/STAT User's Guide, 6th ed. SAS Institute Inc., Cary, NC, USA, 1996.

Shen, K., Wang, X., Luo, X., 1997. Test and demonstration on wetcultivation with film mulching of rice. Hubei Agric. Sci. 5, 1822 (in Chinese).

Timsina, J., Connor, D.J., 2001. Productivity and management of rice-wheat cropping systems: issues and challenges. Field Crops Res. 69, 93-132.

Wilson, D.J., Jefferies, R.L., 1996. Nitrogen mineralization, plant growth and goose herbivory in an Arctic coastal ecosystem. J. Ecol. 84, 841-851.

Wu, L.H., Zhu, Z.R., Liang, Y.C., Shi, W.Y., Zhang, L.M., 1999. The development of the rice film mulching cultivation. J. Zhejiang Agric. Univ. 25, 41-42.

Yadav, R.L., Dwivedi, B.S., Pandey, P.S., 2000. Rice-wheat cropping system: assessment of sustainability under green manuring and chemical fertilizer inputs. Field Crops Res. 65, $15-30$.

Yan, X., Du, L., Shi, S., Xing, G., 2000. Nitrous oxide emission from wetland rice soil as affected by the application of controlledavailability and mid-season aeration. Biol. Fertil. Soil 32 (1), 60-66.

Yoshinori, M., Kanno, T., 1997. Emissions of trace gases $\left(\mathrm{CO}_{2}, \mathrm{CO}\right.$, $\mathrm{CH}_{4}$, and $\mathrm{N}_{2} \mathrm{O}$ ) resulting from rice straw burning. Soil Sci. Plant Nutr. 43, 849-854.

Zhu, Z.L., 1997. Fate and management of fertilizer nitrogen in agroecosystems. In: Zhu, Z., Wen, Q., Freney, J.R. (Eds.), Nitrogen in Soils of China. Kluwer Academic Publishers, Dordrecht, The Netherlands, pp. 239-279.

Zhu, Z.L., 1999. Soil nitrogen fertility and agricultural nitrogen management in China. In: Shen, S.M. (Ed.), Soil Fertility in China. Science Press, Beijing, China, (in Chinese), pp. 160-211. 